\title{
ENFORCING AMERICAN LETTERS OF REQUEST: THE FICKLE CHARTER GUARANTEE OF EVIDENTIARY IMMUNITY
}

\author{
MARY ANNE VALLIANATOS*
}

This article provides an overview of the US Fifth Amendment and Canadian Charter protections on the right against self-incrimination. It provides an in-depth analysis on the current uneven legal framework in the context of extraterritorial evidence gathering, and the constitutional problem of compelled testimony in cross-border proceedings. The author argues that a partial solution can be crafted within the courts by requiring US protective orders prior to enforcing letters of request. Such an approach should reflect the established Charter principle that compulsion must be coupled with evidentiary immunity.
Cet article donne un aperçu du cinquième amendement de la Constitution américaine et des protections garanties en vertu de la Charte canadienne quant au droit de ne pas s'incriminer. L'article fait l'analyse en profondeur du cadre juridique, actuellement inégal, dans le contexte de la preuve extraterritoriale recueillie et $d u$ problème constitutionnel de témoignages forcés dans les poursuites transfrontalières. L'auteur fait remarquer que les tribunaux américains peuvent proposer une solution partielle en exigeant des ordonnances préventives américaines avant l'exécution des lettres de demande. Une telle approche devrait refléter le principe établi de la Charte, notamment que la contrainte doit être assortie d'immunité de preuve.

\section{TABLE OF CONTENTS}

I. INTRODUCTION . . . . . . . . . . . . . . . . . . . . . . . . . 869

II. OVERVIEW: THE FIFTH AMENDMENT AND CHARTER PROTECTIONS

AgAinSt SELF-INCRIMINATION . .................... 871

III. LEGAL FRAMEWORK: GATHERING EVIDENCE IN CANADA . . . . . . . . . 873

A. Letters of Request At Common LaW . . . . . . . . . . . . . . . 873

B. ENFoRCEMENT, Public Policy, AND SOVEREIGNTY . . . . . . . 874

C. LetTERS OF REQUEST UNDER THE HAGUE CONVENTION . . . . . . . 876

IV. EMERGING DOCTRINES: ADJUDICATING EXTRATERRITORIAL AsSERTIONS OF THE FIFTH AMENDMENT . . . . . . . . . . . . . 877

V. Analysis: The Constitutional Problem of Compelled

Testimony in CRoss-Border ProceEdings . . . . . . . . . . . . . 880

A. PRINCIPLES OF CANAdiAN EVIDENTIARY IMMUNITY . . . . . . . . 880

B. LOSING SUBSEQUENT USE IMMUNITY UNDER

THE EMERGING DOCTRINES . . . . . . . . . . . . . . . . . 882

VI. RECOMMENDATION: TOWARDS A COHERENT LEGAL FRAMEWORK . . . . 883

A. American Protective Orders . . . . . . . . . . . . . . . . . . . 884

B. AtTemPting to RestoRe SubSEQUent Use IMmunity . . . . . . . . 885

VII. CONCLUSION ................................ 887

\section{INTRODUCTION}

American Constitutional protections cannot be invoked extraterritorially in a Canadian court. Yet, resistant witnesses in cross-border litigation repeatedly attempt to avail

BA (McGill); JD (Dalhousie); LLM (Columbia); of the British Columbia Bar. The author is grateful to Daniel C Richman, Professor of Law, Columbia Law School and two anonymous reviewers for their invaluable comments. 
themselves of the Fifth Amendment ${ }^{1}$ privilege against self-incrimination. Sir Conrad Black made such an attempt during the highly publicized American criminal investigations into Hollinger Inc. Among other things, Black argued that he should not be compelled to testify in a Canadian civil investigation. Compulsion, he argued, would prejudice his right against self-incrimination under the American and Canadian constitutions. ${ }^{2}$ He argued that his answers in response to the civil investigation under the Canada Business Corporations $\mathrm{Act}^{3}$ would inevitably end up in the hands of the United States Securities \& Exchange Commission, and potentially a grand jury criminal investigation in Illinois. Black sought to stay the $C B C A$ investigation until the resolution of any US criminal action. The Ontario Court of Appeal held, that since criminal charges had yet to be laid in the US, any potential prejudice to Black's self-incrimination right was speculative, and he was not entitled to a stay. ${ }^{4}$ Further, the Court reiterated that, for witnesses, there is no right against compulsion under the Charter of Rights and Freedoms. ${ }^{5}$

As a civil witness, Black had no right to silence, not under the Charter and certainly not under the Fifth Amendment. At issue in the case was whether the self-incrimination privilege under either constitution could be relied on to obstruct a Canadian proceeding in light of ongoing (or likely) American proceedings. Interestingly, the same judicial approach has emerged in cases that involve no Canadian proceeding, but only American litigation. This is true for letters rogatory cases, where Canadian appellate and trial courts have predominately held that witnesses have no right to silence under either constitution on the basis of potential self-incrimination to resist cross-border evidence gathering. The approach has the anomalous effect of denying a witness to an American private civil suit Fifth Amendment protection. This is a dramatic departure from the protection offered by the privilege against self-incrimination within proceedings occurring exclusively within the jurisdiction of either the US or Canada. Both countries have a constitutional guarantee against compelled self-incrimination, however the different nature of the constitutional protections has resulted in a legal idiosyncrasy in which certain witnesses cannot rely on the right afforded by either constitution.

This article begins with an overview of the different approaches of protecting the right against self-incrimination in the US and Canada in Part II. Part III outlines the nature of requests for judicial assistance. Part III then narrows to describe the principles that support the enforcement of foreign letters of request in Canada and the common law test applied by the Ontario and British Columbia courts. Part IV identifies and summarizes the two emergent doctrines relied on by the courts to compel testimony from resistant witnesses without securing evidentiary immunity. Part $\mathrm{V}$ offers an evaluation and determines that the present approaches fail to pass scrutiny under section 13 of the Charter. Part VI proposes a partial solution, concluding that as a precondition to the enforcement of US letters of request in Canada, a protective order should be obtained from an American court over any compelled testimony that has the possibility to undermine a witness's right against self-incrimination.

US Const amend V.

Catalyst Fund General Partner I Inc v Hollinger Inc (2005), 79 OR (3d) 70 (CA) at para 3 [Catalyst]. RSC 1985 с C-44, s 229 [CBCA].

Catalyst, supra note 2 at paras $9-10$.

Ibid at para 4; Canadian Charter of Rights and Freedoms, Part I of the Constitution Act, 1982, being Schedule B to the Canada Act 1982 (UK), 1982, c 11, ss 7, 13 [Charter]. 


\section{Overview: The Fifth Amendment And Charter Protections AgAinST SELF-INCRIMINATION}

In general, letters rogatory cases that grapple with the legality of asserting the Fifth Amendment extraterritorially share three basic characteristics: (1) a civil case is initiated in the US, such as a shareholder class action; (2) counsel to the US civil suit seeks to obtain testimonial evidence from a Canadian resident to advance the case; and (3) the Canadian resident refuses to answer questions, or attend an examination, on the ground that her Fifth Amendment self-incrimination privilege is compromised by the sought testimony. The Canadian court with jurisdiction over evidence gathering procedures must then determine whether the witness should be compelled to attend the examination, notwithstanding her reliance on the Fifth Amendment privilege. Typically, the courts have held that the privilege lacks extraterritorial legal force. ${ }^{6}$ Further, the applicable Canadian counterpart under the Charter does not grant civil witnesses a right to silence in the face of potential criminal selfincrimination, foreign or domestic. ${ }^{7}$

If Conrad Black's case had occurred wholly within US jurisdiction, he could not have been compelled to testify under the Constitution's self-incrimination clause. The Fifth Amendment states that no person "shall be compelled in any criminal case to be a witness against himself." In a civil proceeding, this means that a witness may refuse to answer incriminating questions if she has a reasonable belief that an answer could be used against her in a later criminal case. ${ }^{8}$ A witness cannot completely refuse to testify, but may object to specific questions that may be incriminatory. ${ }^{9}$ In each case, a judge must be satisfied that there is a "real and appreciable" possibility for self-incrimination. ${ }^{10}$ The real and appreciable possibility standard does not require that criminal charges are already laid against the witness. $^{11}$

Provided that the witness's fear of self-incrimination is valid, the witness can be compelled to testify in the US if granted sufficient immunity from the use of her testimony for criminal prosecution. Statutory immunity offers sufficient protection because it is a promise from the government not to use any incriminatory evidence that results from the witness's testimony in a criminal case against the witness. The promise satisfies the

See e.g. United States v Pressey (1988), 65 OR (2d) 141 (CA) [Pressey], leave to appeal to SCC refused, 21077 (8 June 1989); Echostar Satellite Corp v Quinn, 2007 BCSC 1225, 71 BCLR (4th) 172 [Echostar]; Davidson v Barnhardt, 2012 ONSC 6016, 113 OR (3d) 475 [Davidson]; Somerset Pharmaceuticals Inc v Interpharm Inc (1994), 109 DLR (4th) 593 (Ont Ct J (Gen Div)). For cases denying Fifth Amendment protection and ordering testimonial compulsion not pursuant to letters rogatory see Royal Trust Corp of Canada v Fisherman (2000), 49 OR (3d) 187 (Sup Ct J) [Royal Trust], leave to appeal to SCC refused, 28353 (14 June 2001); Hollinger Inc v The Ravelston Corp, 2008 ONCA 207, 89 OR (3d) 721 [Hollinger], leave to appeal to SCC refused, 32665 (9 October 2008); Sun-Times Media Group v Black, [2007] OJ No 795 (QL) (Sup Ct J) [Sun-Times], aff'd 2007 CarswellOnt 2178 (WLCan) (Div Ct); Gillis v Eagleson (1995), 23 OR (3d) 164 (Sup Ct J (Gen Div)) [Gillis]; Hallstone Products Ltd v Canada (Customs \& Revenue Agency) (2005), 140 CRR (2d) 233 (Ont Sup Ct J), rev'd (2006), 82 OR (3d) 368 (Sup Ct J) [Hallstone]; National Financial Services Corp v Wolverton Securities Ltd (1998), 46 BCLR (3d) 275 (SC) [Wolverton Securities], leave to appeal to BCCA granted with stay (1998), 160 DLR (4th) 688 (BCCA); R v Eurocopter Canada Ltd (2004), 185 CCC (3d) 233 (Ont Sup Ct J) [Eurocopter].

Supra note 5, s 13.

Kastigar v United States, 406 US 441 at 444-45 (1972) [Kastigar]; Murphy v Waterfront Commission of New York Harbor, 378 US 52 at 79 (1964) [Murphy].

Anglada $v$ Sprague, 822 F 2d 1035 at para 6 (11th Cir 1987).

Marchetti $v$ United States, 390 US 39 at 48 (1968) [Marchetti].

Wehling v Columbia Broadcasting System, 608 F 2d 1084 at 1087, n 5 (5th Cir 1979). 
constitutional privilege by placing the witness in the same position as if she had claimed the privilege and refused to provide prejudicial answers. ${ }^{12}$ However, only state prosecutors and Department of Justice officials can grant sufficient use and derivative use immunity. Under the federal immunity statute only the US attorneys, with the approval of the Attorney General, have authority to grant such immunity. ${ }^{13}$ If the government is not a party to the private civil litigation, statutory immunity is not available to the witness, and it is unconstitutional to compel testimony from a witness who reasonably believes that her answers would be incriminatory.

In contrast, the Charter does not permit a civil witness to remain silent. Only the accused in a criminal proceeding may assert the right not to testify. ${ }^{14}$ There is no right against compulsion for witnesses because the Charter and the Canada Evidence Act ${ }^{15}$ seek to strike a "different bargain" from the right to silence provided by the Fifth Amendment. ${ }^{16}$ Section 13 of the Charter states:

\footnotetext{
A witness who testifies in any proceedings has the right not to have any incriminating evidence so given used to incriminate that witness in any other proceedings, except in a prosecution for perjury or for the giving of contradictory evidence. $^{17}$
}

Therefore, the Charter requires that a witness provide an incriminatory answer, but is protected from the use of any compelled incriminatory evidence. The result of the contrasting self-incrimination protection schemes is a constitutional blind spot. By compelling testimony pursuant to an American letter of request, a witness may lose protection that would be guaranteed to her if the litigation were carried out exclusively within either legal system. The approach permits compulsion that is both illegal in the US without a statutory grant of immunity, and impossible in Canada without the Charter protection assured in domestic civil and criminal law suits.

Given that neither constitutional order independently supports non-immunized testimonial compulsion, this area of law would benefit from clarification and principled evaluation. The issue has yet to be dealt with by the Supreme Court of Canada ${ }^{18}$ despite the increasingly intertwined nature of international business and coordinated criminal law and regulatory

Kastigar, supra note 8 at 458-59; Zicarelli v New Jersey State Commission of Investigation, 406 US 472 at 475-76 (1972). The federal guarantee provides "Whenever a witness refuses, on the basis of his privilege against self-incrimination, to testify or provide other information in a proceeding ... the witness may not refuse to comply with the order on the basis of his privilege against self-incrimination; but no testimony or other information compelled under the order (or any information directly or indirectly derived from such testimony or other information) may be used against the witness in any criminal case, except a prosecution for perjury, giving a false statement, or otherwise failing to comply with the order." 18 USC $\S 6002$ (2000).

18 USC $\S 6003(\mathrm{~b})$.

Charter, supra note 5, s 11(c).

RSC 1985, c C-5 [CEA].

$R$ v Noël, 2002 SCC 67, [2002] 3 SCR 433 at para 22, Arbour JA.

Charter, supra note 5, s 13.

Leave to appeal has been refused in four cases, two cases specifically on the enforceability of letters of request in light of alleged fear of loss of the privilege. Cases on letters of request include: Pressey, supra note 6; Treat Canada Ltd v Leonidas, 2012 ONCA 748, 273 CRR (2d) 340 [Treat Canada], leave to appeal to SCC refused, 35160 (23 May 2013). Cases refusing leave on the right to silence regarding the threat of US criminal prosecution include: Hollinger, supra note 6; Royal Trust, supra note 6. 
efforts by governmental bodies seeking to regulate those enterprises. ${ }^{19}$ Indeed, this interconnected economic and legal environment leads to greater emphasis on the legal principle of comity in the enforcement of US letters rogatory. The next section of this article further describes the legal test and guiding principles applied by Canadian courts to grant or refuse foreign requests for judicial assistance.

\section{LEGAL FRAMEWORK: GATHERING EVIDENCE IN CANADA}

In spite of the apparent protective gap created by the divergent self-incrimination regimes, the growing body of Canadian case law indicates that witnesses in Canada may not rely on foreign privileges or constitutional protections, absent specific terms of the letter rogatory that allow their application. ${ }^{20}$ The governing authority is Pressey, wherein the Ontario Court of Appeal held that, in refusing to answer under the American privilege, the resistant witness, (a Canadian resident) was trying to get privileges over and beyond that offered in a Canadian forum. ${ }^{21}$ To appreciate the Court's holding in Pressey, one must first grasp the nature of letters rogatory and the existing common law framework. This section discusses the Canadian common law approach to adjudicating foreign requests to obtain evidence in Canada. It concludes by explaining the international alternative to common law letters rogatory - letters under the Convention on the Taking of Evidence Abroad in Civil or Commercial Matters. ${ }^{22}$ Letters rogatory are necessary in Canada because US subpoenas or orders for depositions are not enforceable in Canada. ${ }^{23}$ While the US is a signatory to the Hague Convention, Canada is not. In the absence of a bilateral treaty on evidence gathering in civil matters, Canadian courts remain preoccupied with applying the common law letters rogatory test.

\section{A. LeTters OF REQUEST AT COMMON LAW}

Letters rogatory or letters of request are a form of international judicial assistance in which a court issues a formal written request to a foreign court for assistance in obtaining evidence within the foreign court's jurisdiction. ${ }^{24}$ A non-party witness residing in Canada may only be compelled to provide evidence for a US civil proceeding by a Canadian court order ${ }^{25}$ For example, if a civil action is initiated in Illinois and a potential witness resides in Ontario, the American party will apply to the appropriate and competent Illinois court for a letter of request. If the Illinois court is satisfied that the request is warranted, it will issue the formal letter of request. The request should specify the evidence sought, from whom it is sought, and how it is to be obtained. Next, the Illinois party will file a motion with an Ontario court to enforce the letter. Any order directing the witness to attend for examination is therefore a L Rev 671 at $687-89$.

See e.g. MAN Aktiengesellschaft $v$ Valentini (2006), 81 OR (3d) 680 at para 15 (Sup Ct J) [Valentini] (parties agreed to include a term in the letter rogatory permitting the witness to rely on the Fifth Amendment).

Pressey, supra note 6 at 145.

2218 March 1970, 847 UNTS 231 (entered into force 7 October 1972 in respect of Norway, Denmark and the United States), 8 ILM 37 [Haque Convention].

23 Bradley J Freedman \& Gregory N Harney, "Obtaining Evidence From Canada: The Enforcement of Letters Rogatory by Canadian Courts” (1987) 21:2 UBC L Rev 351 at 352.

$24 \quad$ Ibid at 352. See also Tiedeman $v$ The Signe, 37 F Supp 819 (D La 1941).

25 Peter Sankoff, The Portable Guide to Witnesses, 3rd ed (Toronto: Carswell, 2014) at 103. 
Canadian court order governed by substantive Canadian law. A letter rogatory is unnecessary if a non-party witness is willing to provide evidence to a private foreign litigant since there are no formal domestic rules that regulate such evidence gathering. ${ }^{26}$

Requests for judicial assistance in evidence gathering are anchored in the principle of international comity. ${ }^{27}$ The function of the principle and the enforcement of letters of request were explained by Justice Dickson in Zingre v. The Queen:

It is upon this comity of nations that international legal assistance rests. Thus the courts of one jurisdiction will give effect to the laws and judicial decisions of another jurisdiction, not as a matter of obligation but out of mutual deference and respect. A foreign request is given full force and effect unless it be contrary to the public policy of the jurisdiction to which the request is directed ... or otherwise prejudicial to the sovereignty or the citizens of the latter jurisdiction. ${ }^{28}$

"Comity refers to informal acts performed and rules observed by states in their mutual relations out of politeness, convenience and goodwill, rather than strict legal obligation."29 International judicial co-operation between friendly nations also reflects an "enlightened selfinterest." ${ }^{30}$ Citing Chief Justice Marshall in Schooner Exchange v. M'Faddon, Justice Dickson observed, "common interest impels sovereigns to mutual intercourse and an interchange of good offices with each other." ${ }^{\text {"1 }}$

Since Zingre, Canadian courts have adopted an increasingly liberal approach to granting letters of request. The principle of comity has meant applying a broad and liberal construction to the terms in letters rogatory and section 46 of the CEA. ${ }^{32}$ While the Court in Zingre was of the view that letters of request were typically only enforced for the purpose of gathering evidence to be used at trial, the Court recognized that in limited circumstances Canadian courts granted orders for examination at the pre-trial stage. Today it is commonplace for courts to enforce pre-trial foreign requests for evidence and discovery. ${ }^{33}$

\section{B. Enforcement, Public Policy, And Sovereignty}

Applications for orders to take evidence or to produce documents in Canada for use by American courts are governed by Canadian legislation and factors crafted by the courts. The

mela D Pengelley, “A Compelling Situation: Enforcing American Letters Rogatory in Ontario” (2006) 85 Can Bar Rev 345 at 345; Freedman \& Harney, supra note 23 at 352. See also Ronald E Myrick, “Obtaining Evidence Abroad for Use in United States Litigation” (1991) 15:1 Suffolk Transnat'l L Rev 1 at 42 (author notes that evidence could be obtained by complying with the notice and commission procedures under Fed R Civ P 28(b)).

Zingre $v$ The Queen, [1981] 2 SCR 392 at 401 [Zingre].

Ibid at 401 [citation omitted].

$R v$ Hape, 2007 SCC 26, [2007] 2 SCR 292 at para 47, Binnie JA [citation omitted].

France (Republic) v De Havilland Aircraft of Canada Ltd (1991), 3 OR (3d) 705 at 716 (CA) [De Havilland]; Spencer v The Queen, [1985] 2 SCR 278 at 283 (Estey JA adopted the American definition of comity citing Hilton $v$ Guyot, 159 US 113 at 163-64 (1895)).

31 Zingre, supra note 27 at 400-401, citing Schooner Exchange v M'Faddon, 11 US 116 at 136-37 (1812).

32 Freedman \& Harney, supra note 23 at 357; United States v Royal American Shows Inc, [1982] 1 SCR 414 at 421. See also applicable Ontario and British Columbia legislation: Evidence Act, RSO 1990, c E.23, s 60 [OEA]; Evidence Act, RSBC 1996, c 124, s 53 [BCEA].

33 Freedman \& Harney, ibid at 367. See Re Friction Division Products and EI Du Pont de Nemours \& Co (No 2) (1986), 56 OR (2d) 722 (H Ct J) [Friction Division]. 
test laid down in Friction Division requires that, before a court exercises discretion to grant letters of request, the applicant must establish that:

(1) the evidence sought is relevant;

(2) the evidence sought is necessary for trial and will be adduced at trial, if admissible;

(3) the evidence is not otherwise obtainable;

(4) the order sought is not contrary to public policy;

(5) the documents sought are identified with reasonable specificity; and

(6) the order sought is not unduly burdensome, having in mind what the relevant witnesses would be required to do, and produce, were the action to be tried [in the Canadian court's jurisdiction]. ${ }^{34}$

For witnesses challenging the validity of foreign letters of request for fear of losing the privilege against self-incrimination, factors (4) and (6) are most relevant. By "not contrary to public policy" what is meant is that the request, if enforced, should not prejudice national sovereignty. ${ }^{35}$ National sovereignty will be considered prejudiced if the request (1) would give extraterritorial authority to foreign laws which violate relevant federal or provincial laws, or (2) infringe on recognized Canadian moral or legal principles. ${ }^{36}$ Therefore, public policy concerns include concerns such as the constitutional or fundamental rights of the proposed witness, including a fear of lost subsequent use immunity over compelled incriminatory testimony. ${ }^{37}$ However, it is a "rare occasion" for a US court request to be found to violate the public policy of Canada. ${ }^{38}$ There are a few stated exceptions where comity is overridden by sovereignty and the request refused. ${ }^{39}$

One such circumstance is where the purpose of the request is to use the person's testimony against that person in the requesting country. For example, in Re Uszinska, the Court denied French authorities their request because it was contrary to public policy. ${ }^{40}$ Uszinska was accused of a criminal offence in France, and the evidence sought was intended to incriminate her in the French criminal trial. The Court reasoned that to compel testimony from an accused to further a foreign criminal prosecution, would deny her the full protection of the criminal process, violate Canadian law, and amount to a clear violation of Canadian public policy. In the context of an American civil proceeding where evidence is sought from a

Friction Division, ibid at 732.

Gulf Oil Corp v Gulf Canada Ltd, [1980] 2 SCR 39 at 62.

De Havilland, supra note 30 at 718-19.

Connecticut Retirement Plans and Trust Funds v Buchan, 2007 ONCA 462, 225 OAC 106 at para 26; Treat Canada, supra note 18 at para 50.

Pengelley, supra note 26 at 360. Such a rare occasion occurred in Re Westinghouse Electric Corp and Duquesne Light Co (1977), 16 OR (2d) 273 (H Ct J) in which the Attorney General of Canada intervened in the case, asserting that disclosure would be harmful to the public interest. A US federal court sought to examine a government official on a manner expressly prohibited under the Atomic Energy Control Act, RSC 1970, c A-19 as repealed by Nuclear Safety and Control Act, SC 1997, c 9. The dispute arose in connection to American litigation alleging that several foreign governments were involved in an illegal uranium cartel. Eventually, US letters of request were refused by the courts in Australia, Canada, France, and South Africa. For a discussion of the case on this issue see Thomas Land Fowler, "Letters Rogatory: Current Problems Facing International Judicial Assistance” (1979) 4:3 NCJ Intl L \& Com Reg 297 at 304-306, 309-10.

Zingre, supra note 27 at 401-402 (exceptions include requests that are overly vague, would violate local civil procedure rules, appear to be blatant fishing expeditions and where compliance would be an offence under Canadian criminal laws).

Re Uszinska and the Republic of France (1980), 27 OR (2d) 604 (H Ct J) at 607 [Re Uszinska]; Freedman \& Harney, supra note 23 at 375-76. 
witness located in Canada, it is unlikely that a letter of request, on its face, would resemble the French request in Re Uszinska. ${ }^{41}$ Accordingly, establishing a violation of Canadian public policy is a high threshold for a witness to achieve.

The sixth factor, that an order should not unduly prejudice or burden private interests, is also a challenging factor on which to contest letters rogatory. Historically, this limitation was an "absolute rule." ${ }^{2}$ Courts no longer reject requests that are burdensome or broad. Instead, in response to witness concerns, courts often impose conditions within their orders to lessen the burden or narrow the parameters of a term. ${ }^{43}$ Although enforcement is a discretionary decision that rests on the authority of a Canadian court, US requests are typically given full force and are infrequently held to be "contrary to public policy" or "prejudicial to the sovereignty” of Canada.

\section{LETTERS OF REQUEST UNDER THE HAGUE CONVENTION}

As stated, Canada has not ratified the Hague Convention. If Canada were to become a signatory, it would move closer to closing the self-incrimination loophole in cross-border civil proceedings because of the Convention's standardized evidence gathering procedures. This section briefly addresses how letters of request under the Hague Convention differ from those under the common law and possible reasons why Canada has yet to ratify the Convention. A key difference between requests under the Hague Convention and the common law Friction Division test, is that granting Convention letters of request is not a matter of judicial discretion. A contracting state has an obligation to enforce the letters of request unless the request is (1) beyond the scope of the judiciary's function, (2) does not comply with the Hague Convention's formal requirements, or (3) would prejudice the receiving state's sovereignty or security. ${ }^{44}$

Importantly, the Convention provides means to ensure that individual rights and privileges are not lost in cross-border investigations. Article 11 of the Hague Convention would allow a person to refuse to give evidence on the basis of privileges available in Canada, the US, or a third state. ${ }^{45}$ However, a person can only invoke the privileges available in the US or third state if specified in the letter. Signatories of the Hague Convention are encouraged to specify

41 Again, the French authorities relied on letters of request to compel an accused charged under French criminal law to incriminate herself. Because the law on self-incrimination in both the US and Canada do not permit authorities to compel an accused charged with a criminal offence to incriminate themselves, it is unlikely that a US request would mirror the French request in Re Uszinska, ibid. In keeping with the thrust of this article, this is not to say that the effect of granting a US request for the examination of a witness, who expresses concerns for self-incrimination, could not prejudice a witness in the same way that Uszinska, an accused, would have been prejudiced had the request been granted. Freedman \& Harney, ibid at 377.

See e.g. Echostar, supra note 6; Valentini, supra note 20.

Hague Convention, supra note 22, arts 3, 12.

Article 11 of the Hague Convention, ibid states:

In the execution of a Letter of Request the person concerned may refuse to give evidence in so far as he has a privilege or duty to refuse to give the evidence -

a) under the law of the State of execution; or

b) under the law of the State of origin, and the privilege or duty has been specified in the Letter, or, at the instance of the requested authority, has been otherwise confirmed to that authority by the requesting authority.

A Contracting State may declare that, in addition, it will respect privileges and duties existing under the law of States other than the State of origin and the State of execution, to the extent specified in that declaration. 
which privileges are applicable in each request. ${ }^{46}$ This would suggest that, even on Canadian soil, the American Fifth Amendment privileges would become available to witnesses when specified. ${ }^{47}$ This can be contrasted with the existing approach of Canadian courts in letter rogatory cases which grants only Canadian legal protections to witnesses in pre-trial discoveries and examinations under the federal and provincial evidence acts. ${ }^{48}$

It is likely that Canada has not ratified the Hague Convention because the Convention lacks a federal state clause. ${ }^{49}$ Such a clause would permit the federal government to ratify an international treaty only to the extent that international obligations come within federal jurisdiction. ${ }^{50}$ Evidence gathering in civil matters falls within an area of exclusive provincial jurisdiction. ${ }^{51}$ Granted, the federal government has jurisdiction to negotiate and ratify international treaties, but even so it may not rely on this authority to encroach on areas of exclusive provincial jurisdiction. ${ }^{52}$ Therefore, absent a federal state clause, the Federal government may only ratify the Hague Convention with agreement from the provincial legislative assemblies. ${ }^{53}$ Such collective action appears unlikely because both Quebec and Ontario have enacted laws that directly prevent the removal of particular forms of evidence from their jurisdiction. ${ }^{54}$ These "blocking statutes" are intended to shield Canadian businesses and residents from foreign discovery.

\section{EMERGING DOCTRINES: ADJUDICATING EXTRATERRITORIAL ASSERTIONS OF THE FIFTH AMENDMENT}

Although the evidence sought by American letters of request is intended to aid civil litigation in the US, examinations under letters of request are governed by Canadian law. ${ }^{55}$ As a result, a witness may be compelled to testify absent a statutory or constitutional promise of immunity from the use of those answers against her. Courts have summarized the dilemma in the following way:

Hague Conference on Private International Law, Conclusions and Recommendations of the Special Commission on the Practical Operation of the Hague Apostille, Service, Taking of Evidence and Access to Justice Conventions (February 2009) at 9, online: <www.hcch.net/upload/wop/jac_concl_e.pdf> . Myrick, supra note 26 at 51. Consider also the Treaty between the Government of Canada and the Government of the United States of America on Mutual Legal Assistance in Criminal Matters, 18 March 1985, Can TS 1990 No 19 (entered into force 24 January 1990) [MLAT]. The purpose of the MLAT is to improve the effectiveness of investigation, prosecution and suppression of crimes in both countries through mutual assistance. Article II, section 2(e) states that assistance includes "taking the evidence of persons." Of significance is section 18(7) of the Mutual Legal Assistance in Criminal Matters Act, RSC 1985, c 30 (4th Supp), which permits a witness to refuse to answer questions if doing so would violate either section 13 of Charter or the Fifth Amendment (for US see: 28 USC § 1782(a) (1994)). Accordingly, compelled testimony under the MLAT adheres to the fundamental principle against selfincrimination because compulsion is "coupled with full evidentiary immunity": Canada (AG) v Cuenca, [1995] RJQ 1680 (CA) at 1685, leave to appeal to SCC refused, 24909 (8 Feburary 1996). CEA, supra note 15, s 50; OEA, supra note 32, s 60(3); BCEA, supra note 32, s 4(2).

Myrick, supra note 26 at 50.

John H Currie, Public International Law, 2nd ed (Toronto: Irwin Law 2008) at 244.

Constitution Act, 1867 (UK), 30 \& 31 Vict, c 3, reprinted in RSC 1985, Appendix II, No 5, s 92(14). Capital Cities Communications Inc v Canadian Radio-Television Commission, [1978] 2 SCR 141 at 172-73.

Canada, Parliamentary Information and Research Service, “Canada’s Approach to the Treaty-Making Process,” by Laura Barnett, No 2008-45-E (Ottawa: Library of Parliament, 6 November 2012) at 7, online: <www.parl.gc.ca/Content/LOP/ResearchPublications/2008-45-e.pdf>.

Business Records Protection Act, RSO 1990, c B.19, s 1; Business Concerns Records Act, CQLR c D12, s 3; H Patrick Glenn, "Conflicting Laws in a Common Market - The NAFTA Experiment” (2001) 76:3 Chicago-Kent L Rev 1789 at 1808. See also Foreign Extraterritorial Measures Act, RSC 1985, c F-29, s 3.

Pressey, supra note 6 at 143-44. 
American protections ... operate on the "front-end", permitting witnesses to "take the Fifth" when answering a question that would risk incrimination and, therefore, they need not answer the question. Canadian protections ... operate on the back-end, by requiring witnesses to respond, but excluding their answers from subsequent proceedings. Thus, in this case, [the witness] claims to be receiving the worst of both worlds, denied both the right not to respond and the right to have evidence excluded. ${ }^{56}$

As stated in Part III above, the Court in Pressey acknowledged this possible Charter gap. Nonetheless, the Court held that Pressey, a Canadian resident, could not rely on the Fifth Amendment because he would then have privileges beyond those available in a Canadian forum. Following Pressey, two approaches have emerged among the provincial courts in response to witnesses asserting a prophylactic right against self-incrimination. Part IV explains these two approaches and identifies the various remedies granted by the courts.

The first approach is that exemplified in the Pressey case. This is an outright refusal to entertain any extraterritorial application of the Fifth Amendment. ${ }^{57}$ According to this view, because section 13 of the Charter authorizes testimonial compulsion, any possible prejudice to an individual's subsequent use immunity should be argued before an American court. The American court, as the final recipient of compelled testimony, is the proper forum to adjudicate the applicability and merit of a witness' constitutional rights claims. If the witness's fears of foreign prosecution materialize, her right to subsequent use immunity over compelled testimony will turn on the admissibility test applied by a US court. Ontario case law indicates that judges favouring this approach considered it unlikely that compelled responses that incriminate the witness would later be admitted, as this would "shock the judicial conscience" or violate baseline due process requirements with respect to the witness's Fifth Amendment rights. ${ }^{58}$

On the other hand, a more tempered approach among Canadian courts has also emerged. Under this second stream, courts accept that potential criminal prosecution in the US is a relevant factor to consider in adjudicating the enforceability of letters rogatory. ${ }^{59}$ Specifically, courts remain attentive to the possible impact testimonial compulsion may have on subsequent rights to immunity and derivative use immunity in the American legal system. ${ }^{60}$ For example, in Sun-Times, the Ontario Superior Court cautioned: "[t]here is more than a risk that compelled testimony given in Canada without the protection of the Fifth Amendment to the United States Constitution might well find its way into the hands of the U.S. prosecution and before the U.S. Criminal Courts."61 Additionally, the potential for a Canadian order to undermine an individual's rights in a foreign jurisdiction, may be a factor for the court's consideration: "a Canadian court should not turn a blind eye to the possible consequences

$56 \quad$ Hallstone, supra note 6 at para 17. See also Echostar, supra note 6 at para 78.

Davidson, supra note 6 at para 18; Echostar, supra note 6 at para 84; Royal Trust, supra note 6 at paras 38-41. See also the Superior Court's rejection of extending s 24(1) of the Charter to craft a pre-emptive protection against a "future or imminent" violation of s 13 in $R v$ Gordon (1998), 130 CCC (3d) 129 at paras 80-85 (Ont Sup Ct).

$58 \quad$ Davidson, ibid at paras 18-19; Royal Trust, ibid at para 39.

$59 \quad$ Aker Biomarine AS v KGK Synergize Inc, 2013 ONSC 4897, 47 CPC (7th) 284 at para 30 [Aker Biomarine].

$60 \quad$ Catalyst, supra note 2 at paras 4-5; Ritter v Hoag, 2004 ABQB 269, 364 AR 204 at para 20; Wolverton Securities, supra note 6 at paras 36-37.

$61 \quad$ Sun-Times, supra note 6 at para 52. 
of compelled testimony outside this country, particularly where the compulsion is at the request of a court of the country where those consequences might materialize."62

Canadian litigants have argued that, by foreclosing arguments based on the Fifth Amendment, the court forces the witness to waive protection under the US self-incrimination clause. ${ }^{63}$ This assertion has some support, but may be overstated. In support of this argument are cases where American courts have held that witnesses waive constitutional protection in circumstances where they refuse to answer questions but fail to explicitly invoke the Fifth Amendment. ${ }^{64}$ Moreover, in US legal proceedings, waiver commonly arises during depositions and from discovery responses. ${ }^{65}$ However, the dominant view is that testimony provided in response to compulsion from a foreign court would not constitute waiver. ${ }^{66}$ This is because no specific words are required to invoke the privilege, and any reference to the Fifth Amendment or self-incrimination is sufficient. ${ }^{67}$ There is also a legal presumption in favour of protecting the privilege. ${ }^{68}$ Nonetheless, judicial concern for potential selfincrimination in the US, resulting from compelled testimony in Canada, has led to a second approach to letters rogatory cases.

This approach requires that the witness establish a real and substantial fear or material risk of foreign criminal prosecution and that the testimony provided in the civil lawsuit will be used in future or concurrent prosecution. In most proceedings disputing letters rogatory, unwilling witnesses have not surmounted this threshold. Presenting evidence of an ongoing criminal investigation, media reports, or civil pleadings that overlap with essential elements of a criminal offence may establish a risk of self-incrimination, but not a material risk. ${ }^{69}$ The starting point for the court's analysis is that the foreign court should be assisted unless there is good reason to the contrary, and the possibility of criminal proceedings appears insufficient to deprive a civil proceeding of the desired evidence. ${ }^{70}$ Consequently, the resisting witness bears the onus of establishing a "material risk" of self-incrimination will flow from the compelled testimony. ${ }^{71}$

It seems that a material risk of incrimination will most probably be found where US criminal charges have been laid against the witness. ${ }^{72}$ This view is supported not by letters rogatory case law, but by independent Canadian civil proceedings that had the potential to undermine witnesses’ rights in the US. For example, in Gillis, a substantial risk of self-

Echostar, supra note 6 at para 62.

Ibid at paras 32-33. See also Gillis, supra note 6 at 167.

Cohran v Carlin, 297 SE (2d) 54 (Ga App Ct 1982).

David A Westrup, “An Introduction to the Right Against Self-Incrimination” in ABA Section of Anti-

Trust Law, The Right Against Self-Incrimination in Civil Litigation (Chicago: American Bar Association, 2001) 1 at 6.

Wolverton Securities, supra note 6 at para 36.

Quinn v United States, 349 US 155 (1955); Emspak v United States, 349 US 190 (1955).

Re Vitamins Antitrust Litigation, 120 F Supp (2d) 58 (D DC 2000).

Wolverton Securities, supra note 6 at paras 42-44 (pleadings alleged unlawful conspiracy to defraud the public by manipulating market price of publicly traded shares; plaintiff filed complaints with US Justice Department and Securities Commission); Echostar, supra note 6 at para 54 (no evidence that US criminal prosecutions were underway or contemplated, but allegations in the civil suit made it a realistic possibility that criminal proceedings might ensue). See also Davidson, supra note 6 at paras 11-13, 17. Note however that the US domestic self-incrimination doctrine does not require the laying of criminal charges to establish a real possibility of incrimination: Marchetti, supra note 10 at 53.

Echostar, supra note 6 at paras 79-80.

See Gillis, supra note 6; Sun-Times, supra note 6; $R$ v Malik, 2003 BCSC 1152, [2003] BCJ No 3177 (QL) at para 131 [Malik]. 
incrimination was proven by virtue of the existing US criminal charges that arose from the same set of facts at issue in the discovery. ${ }^{73}$ Similarly, in Sun-Times, Conrad Black presented evidence that the US prosecutor had served notice of an intention to raise specific issues which overlapped with the evidence sought in the contested summons to witness. ${ }^{74}$ In both cases, the courts looked to the outstanding criminal charges pending in the US against the witnesses as a cogent reason to permit them to not testify. In Black's case, the summons to witness was quashed. In Gillis, the civil discovery was stayed pending the final resolution of the criminal charges.

Under both of these approaches (the real and substantial or material risk of incrimination approach and the blanket refusal to apply the Fifth Amendment approach) Canadian courts consider a variety of orders to respond to the witness's fears. These include sealing court records and transcripts, ${ }^{75}$ requiring undertakings of confidentiality from the examining attorneys, ${ }^{76}$ remaining seized, ${ }^{77}$ and issuing protective orders. ${ }^{78}$ The effectiveness of these measures is debatable, since the extent to which a US court would uphold a foreign court order remains unclear. $^{79}$

\section{Analysis: the Constitutional Problem of Compelling Testimony in Cross-Border ProceEdings}

This section evaluates the approaches adopted by the Ontario and British Columbia courts, which could be viewed as an emerging doctrine in the absence of a Supreme Court decision on the issue. Part V supports the conclusion that, to the extent the emerging doctrines fail to secure subsequent use immunity, they do not comply with the existing parameters of the Charter protection against self-incrimination. Part VI discusses the role of US court protective orders to partially remedy this constitutional loophole.

\section{A. PRINCIPLES OF CANAdian EVIDENTIARY IMMUNITY}

The Charter protection against self-incrimination is a guarantee of subsequent use immunity. In a civil or criminal proceeding, section 13 of the Charter will automatically apply to any incriminatory testimony compelled from a non-defendant witness. No invocation of the provision or the privilege is required. The court will not inquire in to whether or not the witness's answers are potentially incriminatory. However, if in a later criminal trial the Crown seeks to introduce compelled testimony for the purposes of incriminating this witness, the court will then determine whether the statement is

73

Gillis, ibid at 172-73. The defendant was granted the extraordinary remedy of a stay of Canadian civil action for several months until the conclusion of the US criminal proceeding arising from the same facts. This case remains relevant for its discussion of the potential prejudice to the privilege against selfincrimination that results from simultaneous American criminal and Canadian civil proceedings. See e.g. Royal Trust, supra note 6 at paras 27-28.

Sun-Times, supra note 6 at paras 52, 55.

Hallstone, supra note 6.

Angus v Transnational Automotive Group Inc, 2010 BCSC 576, [2010] BCJ No 752 (QL) at paras 57-60 [Angus]. See also Echostar and Davidson, supra note 6.

Catalyst Fund, supra note 2. Note, however this case did not concern a letter rogatory but compulsion to attend before an inspector pursuant to the $C B C A$ simultaneously when Black faced criminal investigation in the US arising out of substantially the same facts. Aker Biomarine, supra note 59 at para 30.

Sun-Times, supra note 6 at para 59. 
incriminatory. ${ }^{80}$ Evidence is "incriminatory" if the Crown could use it to prove guilt, "i.e., to prove or assist in proving one or more of the essential elements of the offence for which the witness is being tried." 81 The court is to assess the nature of the evidence, rather than the Crown's purpose for its introduction. ${ }^{82}$ The rationale underlying the Canadian protective regime is often referred to as a constitutional bargain or quid pro quo arrangement. In exchange for the witness's full and frank testimony, the state undertakes not to use incriminatory evidence or evidence derived solely from it against the witness in any future proceeding, except to prosecute perjury. ${ }^{83}$ The purpose of section 13 is only a right to use immunity. The Charter regime protects the individual from indirectly being made witness against herself, thus ensuring "the Crown will not be able to do indirectly that which s. 11(c) prohibits." ${ }^{84}$ Although a witness has no right against compulsion, the privilege against selfincrimination is considered a basic tenet of the Canadian legal system carrying normative significance. ${ }^{85}$ For two decades the Supreme Court has deemed the privilege a "fundamental principle of justice.” 86

Witnesses have argued that the right to silence that an accused is entitled to under section 7 of the Charter should apply, or that section 13 should have a prophylactic effect. Both assertions have been squarely rejected by the courts. In R. v. S. (R.J.), pointing to the longevity of the CEA and its ability to survive "unending scrutiny," the Supreme Court concluded that the drafters of the Constitution did not intend to replicate the Fifth Amendment to the US Constitution: "the American model, 'complete with its residual doctrines,' ... was specifically considered and rejected [by the Constitution's drafters]."87 Witnesses have attempted to carve out an exception to this interpretation of sections 7 and 13 on the basis that the Supreme Court did not contemplate a threat of foreign prosecution. On this point the lower courts have concluded that the right to silence, or a constitutional exemption from testimonial compulsion, is only available if the predominant purpose of the sought examination is to prosecute the witness in Canada. ${ }^{88}$

$R v$ Nedelcu, 2012 SCC 59, [2012] 3 SCR 311 [Nedelcu].

Ibid at para 9. Contra Paul Calarco, "R. v. Nedelcu: Whatever Happened to a Large and Liberal Interpretation of Charter Rights?” (2012) 96 Criminal Reports (6th) 438 at 443 (WL) (evidence that destroys the credibility of an accused is indirectly incriminatory).

Lisa Dufraimont, "Section 13 Use Immunity After R. v. Nedelcu” (2012) 96 Criminal Reports (6th) 431 at 432 (WL). This approach to assessing admissibility of prior compelled testimony in criminal proceedings departs from the Supreme Court's earlier s 13 jurisprudence which allowed the Crown to rely on incriminatory testimony for the purpose of impeaching the accused's credibility ( $R v$ Kuldip, [1990] 3 SCR 618), and later forbade the introduction of any compelled testimony regardless of the purpose for which the Crown sought to use it ( $R$ v Henry, 2005 SCC 76, [2005] 3 SCR 609 [Henry]). Nedelcu, supra note 80 at paras 6-7; Henry, ibid at para 22.

Henry, ibid at para 2. Section 11(c) of the Charter, supra note 5 states: "Any person charged with an offence has the right not to be compelled to be a witness in proceedings against that person in respect of the offence."

$R$ v P (MB), [1994] 1 SCR 555 at 577, Lamer CJ.

Ibid at 577-78. See also Canada (AG) v Bedford, 2013 SCC 72, [2013] 3 SCR 1101 at para 96 (defining the principles of fundamental justice as a judicial mechanism to strike down "inherently bad laws" that run "afoul” of the country's “basic values”).

$R v S(R J)$, [1995] 1 SCR 451 at 533 [citation omitted].

Malik, supra note 72 at paras 112, 121-40; Catalyst, supra note 2 at para 9. See also Manitoba (AG) v Clark, 2013 MBQB 249, 298 Man R (2d) 169. 


\section{B. LOSING SUBSEQUENT USE IMMUNITY UNDER THE EMERGING DOCTRINES}

The two approaches described above compel testimony without securing evidentiary immunity in cases regarding contested letters rogatory. For the individual compelled to give evidence, these approaches forfeit half the Charter promise found in section 13 . The first approach rejects the extraterritorial application of the US right to silence. Under this approach, because Canadian law governs evidence gathering under a letter of request and the Charter does not recognize a right to silence for witnesses, it follows that there can be no right against compulsion. Testimony may be compelled and relied on in US proceedings, presumably on public record. Recall that under US Federal law, the Attorney General has the power to grant statutory immunity to a witness in exchange for her testimony in criminal proceedings. However, in private civil litigation, such statutory protection is not available to the witness. Consequently, in a US civil proceeding, the Fifth Amendment prohibits the court from compelling testimony that a witness reasonably believes is incriminatory. Once a Canadian court compels testimony from a witness, she will not be protected by a US grant of statutory immunity. However, in such cases Canadian courts will usually impose ethical constraints on counsel involved in the civil case, such as by requiring the lawyers to undertake to not jeopardize the witness's self-incrimination privilege.

Perhaps, courts have failed to construct remedies that adequately uphold immunity rights due to a failure to view domestic rights cases with foreign elements as a coherent legal category. ${ }^{89}$ Rather than treating letters rogatory cases as an exception to a fundamental trial right, the law might craft guarantees at the intersection of private foreign action and domestic state action that flow from the Charter's domestic objective. ${ }^{90}$ As discussed in Part VI below, Canadian courts could revisit the common law test regarding US letters rogatory. Before ordering testimonial compulsion, the courts could require preconditions as part of the terms of the letter, thereby relying on US legal mechanisms to parallel the promise of immunity that would otherwise have been available to the witness in Canada. For the time being, this could be partially accomplished through reliance on US protective orders.

The second approach requires that the witness establish a material or real and substantial risk of self-incrimination. This method is in line with American constitutional doctrine, but does not flow from established Charter jurisprudence on self-incrimination, which is based on the "constitutional bargain" principle. Fifth Amendment jurisprudence has established that a witness to a civil action may only refuse to answer questions if she faces a "real and appreciable" possibility of self-incrimination. Once the court is convinced that the fear is not insubstantial, the witness can be compelled to testify only if granted sufficient immunity by the state. ${ }^{91}$

This doctrinal approach flows from the US Supreme Court's statement of the principles underlying the privilege: Action, and Fundamental-Rights Cases with Foreign Elements” (2008) 71:3 Law \& Contemp Probs 39 at 56 . 
[The privilege] reflects many of our fundamental values and most noble aspirations: our unwillingness to subject those suspected of crime to the cruel trilemma of self-accusation, perjury or contempt; our preference for an accusatorial rather than an inquisitorial system of criminal justice; our fear that self-incriminating statements will be elicited by inhumane treatment and abuses; our sense of fair play which dictates a fair state-individual balance by requiring the government to leave the individual alone until good cause is shown for disturbing him and by requiring the government in its contest with the individual to shoulder the entire load; our respect for the inviolability of the human personality and of the right of each individual to a private enclave where he may lead a private life; our distrust of self-deprecatory statements; and our realization that the privilege, while sometimes a shelter to the guilty, is often a protection to the innocent. ${ }^{92}$

This principle against subjecting individuals to the "cruel trilemma” of self-accusation, perjury or contempt does not underlay the Canadian understanding of self-incrimination. On the contrary, the Canadian constitutional bargain principle does not support the importation of the American threshold test of real and appreciable risk; the applicability of protection under the Charter is not a threshold question. Instead, section 13 protection is automatic; no showing from the witness is required to earn immunity. This approach reflects an appreciation of the near-impossibility placed on witnesses to prove the incriminatory nature of a line of questioning without incriminating themselves. It also assumes that the same legal system will apply to the subsequent criminal prosecution of the witness, for it is at that later date the court will exclude the use of compelled statements for the purpose of establishing guilt.

In summary, the first approach — which refuses to apply the US constitutional right to silence - is problematic because the court compels testimony without guaranteeing evidentiary immunity for any incriminatory statements. This approach mistakenly surmises that if and when the evidence is sought to be relied on in a US criminal proceeding, previous compulsion in Canada will not undermine the witness's Charter rights. In reality, only a grant of statutory immunity from American authorities is capable of ensuring protection commensurate with that promised by the Charter. Under the second approach, courts entertain the possibility of granting a witness the right to silence, placing an evidentiary onus on the witness to establish the severity and legitimacy of her fear of self-incrimination. However, this front-end analysis is inconsistent with Canadian jurisprudence and principles pertaining to the privilege against self-incrimination. Given that neither approach adheres to section 13 of the Charter, the following section argues for a greater role for US court protective orders to offer more fulsome immunity protection for witnesses in letters rogatory cases. This partial solution also respects the Pressey precedent that American courts are the proper forum to preside over US constitutional arguments.

\section{RECOMMENDATION: TOWARDS A COHERENT LEGAL FRAMEWORK}

The problem canvassed in this article can be partially ameliorated by relying on US court protective orders. Where a witness refuses to testify on the grounds of the self-incrimination privilege, the Canadian court should require that the letter rogatory include a US court protective order before enforcing the request. As a doctrinal matter, the presence or absence of a protective order with the evidentiary request could be considered under the common law 
Friction Division test (described in Part III). Recall that any loss of fundamental rights is sufficient to deny a letter of request on public policy grounds. The first part of this section describes the nature of American protective orders. The second part of this section discusses the feasibility of preconditional US court orders within the Canadian law on letters of request.

\section{A. American Protective Orders}

A protective order prevents "disclosure of information obtained solely as the result of court sanctioned discovery." ${ }^{93}$ Courts are authorized to issue discretionary protective orders under the federal and state codes of civil procedure. For example Rule 26(c) of the Federal Rules of Civil Procedure provides that "the court may, for good cause, issue an order to protect a party or person from annoyance, embarrassment, oppression, or undue burden or expense.” Possible terms of the order include forbidding disclosure to third parties and sealing depositions. Courts retain "a great deal of flexibility in crafting the contents of protective orders." 94

There are three types of protective orders: (1) particular protective orders narrowly apply to specific identified information that have been reviewed and approved by the court; ${ }^{95}(2)$ umbrella protective orders shield all discovery from disclosure without prior review by the parties or the court; and (3) blanket protective orders which require parties to designate documents or information that is entitled to protection. ${ }^{96}$ Blanket protective orders are routinely approved by US courts in civil cases and are viewed as serving "the interests of a just, speedy, and less expensive determination of complex disputes." ${ }^{\text {,7 }}$ The requirement that the requesting party show good cause for the protection means providing a factual showing of the harm to the litigant without such an order. ${ }^{98}$

Protective orders, however are not the judicial equivalent to grants of statutory immunity. Courts cannot simply fashion a "sufficiently durable safeguard for the full protection of the fifth amendment rights” against direct and indirect prosecutorial use required by Kastigar. ${ }^{99}$ Indeed, the orders do not always shield court records from grand jury subpoenas. ${ }^{100}$ Moreover, it is unrealistic to expect a court to hold all proceedings in secret, seal all records

Gillard v Boulder Valley School District, 196 FRD 382 at 387 (D Colo 2000) [Gillard].

Arthur R Miller, “Confidentiality, Protective Orders, and Public Access to the Courts” (1991) 105:2 Harv L Rev 427 at 435.

Bayer AG and Miles Inc v Barr Laboratories Inc, 162 FRD 456 at 465 (D NY 1995).

Gillard, supra note 93 at 387.

Ibid at 386.

Parkway Gallery Furniture Inc v Kittinger/Pennsylvania House Group Inc, 121 FRD 264 at 268 (D NC 1988); Miller, supra note 94 at 434-35.

Andover Data Services v Statistical Tabulating Corp, 876 F (2d) 1080 at 1084 (2nd Cir 1989); James Bogan, “Avoiding the Fifth Amendment Dilemma: Stays and Protective Orders,” in ABA section of Anti-Trust Law, supra note 65131 at 154.

Re Grand Jury Subpoena Duces Tecum, 945 F (2d) 1221 at 1224 (2nd Cir 1991) citing Martindell v International Telephone \& Telegraph Corp, 594 F (2d) 291 at 295 (2nd Cir 1979) [Martindell], the Second Circuit held that a protective order is enforceable against government subpoena. But in Re Grand Jury Subpoena, 836 F (2d) 1468 at 1477 (4th Cir 1988) and Grand Jury Proceedings (Williams) v United States, 995 F (2d) 1013 (11th Cir 1993), the Fourth and Eleventh Circuit courts held that protective orders were insufficient grounds to quash grand jury subpoenas. See also a critique of the Second Circuit's reasons in Ajit Pai, "Should a Grand Jury Subpoena Override a District Court's Protective Order?” (1997) 64:1 U Chicago L Rev 317 at 324-27. 
indefinitely, and prevent all participants from providing information to the government. ${ }^{101}$ Nonetheless, the Second Circuit has upheld protective orders as "fully and fairly enforceable" in circumstances where the order is intended to protect a witness's selfincrimination privilege. ${ }^{102}$ Further, district courts retain the discretion to refuse private and governmental investigative demands in some instances. ${ }^{103}$

Although protective orders have received different treatment within the US courts, there is clearly a role for the orders in carefully limiting the availability of potentially incriminatory testimony. ${ }^{104}$ Therefore, while it cannot be said that a protective order would entirely remove the risk of incrimination, it would improve the chance of suppressing compelled incriminatory testimony from Canada-based witnesses. This is especially so given the unavailability of statutory immunity in a civil action without a government party.

\section{B. ATTEMPTING TO RESTORE SUBSEQUENT USE IMMUNITY}

Although it is far from perfect, more than any other judicial construct an enforceable protective order mirrors the evidentiary immunity regime required by the Charter. The workings of such an order are not dramatically foreign to Canadian judges. In large measure, the courts have struggled to craft precautions that resemble the US court order. Canadian courts have imposed confidentiality orders, sealed records, and attorney undertakings, and granted witnesses anonymity. However, because the binding legality of these orders in the US is questionable, reliance on American protective orders would bring greater clarity to this area of law. As previously stated, this is especially desirable, given that the closest American equivalent to Charter evidentiary immunity, the statutory immunity grant, is typically unavailable in private party litigation.

It is routinely overlooked that in the leading case of Pressey, the US had granted Pressey statutory immunity from US criminal prosecution. ${ }^{105}$ Therefore, unlike the other cases discussed in this article, Pressey had constitutional evidentiary immunity on both sides of the border. The case displayed no asymmetrical protection or idiosyncratic conflict between the two countries' constitutional provisions. This likely explains the Court of Appeal's rejection of Pressey's contention that he was entitled both to statutory immunity and to remain silent, an entitlement that does not exist under either American or Canadian law. The court enforced the New York District Court letter of request and compelled Pressey to testify, correctly finding that a witness had no right to greater protection than was available under the Canadian Constitution. ${ }^{106}$

When Pressey is considered within the case's complete factual context, it does not preclude the new precondition that a letter of request with potentially incriminatory inquiries

Robert H Heidt, “The Conjurer’s Circle — The Fifth Amendment Privilege in Civil Cases” (1982) 91:6 Yale LJ 1062 at 1095.

Martindell, supra note 100 at 295.

United States v GAF Corp, 596 F (2d) 10 at 16 (2nd Cir 1979).

See e.g. Re Perrigo Co, 128 F (3d) 430 (6th Cir 1997) (parties to civil litigation negotiated protective orders for privileged information, and the Court held that submitting such information to a court does not automatically place the documents in the public domain or waive privilege).

Pressey, supra note 6 at 142. For cases overlooking the immunity order see Barnhardt, supra note 6; Royal Trust, supra note 6; EchoStar, supra note 6; Treat Canada, supra note 18 at para 33.

Pressey, ibid at 145. 
should not be granted absent a protective order issued by the requesting US court. On occasion, Ontario courts have stipulated specific preconditions that must be met before US requests will be granted. Of note is Aker Biomarine, where the Ontario Superior Court considered a protective order as a precondition to granting the party's request for evidence. ${ }^{107}$ Without an undertaking under the Federal Rules of Civil Procedure or a protective order for the non-party witness, the Court stated in obiter that the "enforcement of letters rogatory should be regarded as contrary to the public policy of Ontario." ${ }^{108}$ This position is not binding on any court, but it serves as an example of the workability of a new rule of the preconditional protective order. Moreover, it is supported by the practice of the litigants in Treat Canada and Maverick LNG Holdings who appeared before the Ontario and British Columbia courts with American protective orders already in tow. ${ }^{109}$

In terms of formalizing the need for a preconditional protective order in specific cases, it should be recalled that in the absence of Canada's ratification of bilateral or international civil evidence gathering treaties, such as the Hague Convention, the enforcement of letters rogatory remains a discretionary matter for the courts. Therefore, the requirement of a protective order could simply be pursued as judicially crafted common law. Recall that under the Friction Division test, a letter of request may be refused on public policy grounds. Because the public policy exemption includes the consideration of fundamental rights, the capacity of a protective order to secure or ameliorate lost Charter protections could be considered at this stage.

Moreover, according to the Supreme Court, the principle against self-incrimination is an overarching principle from which "specific common law and Charter rules emanate.... The principle can also be the source of new rules in appropriate circumstances."110 Because the courts retain jurisdiction to codify the approach, it is likely that the requirement of a US protective order could be adopted as a rule of civil procedure. To point to an example, Ontario's Courts of Justice Act ${ }^{111}$ empowers a committee of judges and lawyers to author new rules in relation to the examination of witnesses, discovery, pre-hearing disclosure, and enforcement of orders. This statutory prerogative led the Ontario Court of Appeal to observe that "the committee potentially has the authority to pass rules in relation to the enforcement of letters rogatory."112 However, any new rule regarding letters rogatory would have to adhere to the existing framework under each province's respective legislation governing the

Aker Biomarine, supra note 59 at para 30 (letter of request was refused on the grounds that the US court had accepted unproven propositions by the plaintiff/requesting party).

108 Ibid at para 30. But see Angus, supra note 76 at paras 59-60, in which the witness's argument that a protective order should be a precondition was rejected by the court. The witness had failed to lead evidence as to what an American protective order was, or how it would be obtained.

109 Treat Canada, supra note 18 at paras 52-63. The Court of Appeal viewed the requesting party's protective order provided by the District Court for the District of Columbia as adequately responding to the witness's immunity concern; Maverick LNG Holdings Ltd v Teekay Shipping (Canada) Ltd, 2009 BCSC 1538, [2009] BCJ No 2253 (QL) at paras 34, 55 (the protective order granted by the Texas court was considered adequate to shelter particular confidential documents from access and use beyond the US litigation, however, since access to certain financial projections and commercially sensitive information would not be permitted under domestic civil procedure rules, the American protective order was not sufficient to grant plaintiffs discovery over those documents). $R v$ White, [1999] 2 SCR 417 at 438, Iacobucci JA.

RSO 1990, c C.43, s 66(2) [CJA]. For the composition of the Civil Rules Committee, see s 65(2).

Lantheus Medical Imaging Inc v Atomic Energy of Canada Ltd, 2013 ONCA 264, 115 OR (3d) 161 at para 38. 
use of evidence. ${ }^{113}$ Since both federal and provincial acts retain judicial discretion to control the form and process of the examination of witnesses pursuant to a letter rogatory, a new rule stipulating the requirement of a protective order to secure a witness's right to evidentiary immunity would be consistent with existing legislation. ${ }^{114}$

\section{CONCLUSION}

A liberal approach to extraterritorial evidence gathering - guided by the principle of comity - has resulted in an uneven legal framework. American litigants may rely on Canadian courts to secure testimony to assist with litigation in the US, even when the testimony is not obtainable by the parties in the US under the Fifth Amendment. At the same time, witnesses in Canada may be compelled to testify without the protection offered by the privilege against self-incrimination that they would be entitled to if proceedings occurred exclusively within the jurisdiction of either the US or Canada. It is a mistake to permit letters of request to carve out exceptions from fundamental trial rights in this manner merely because of the cross-border nature of the proceedings. Such an approach fails to grasp the interconnected and international nature of businesses and the ongoing regulatory and criminal coordination between governments to monitor those operations.

Considering Canada's obstacles to joining the existing international framework provided under the Hague Convention, this article has argued that a solution can be crafted within the courts, and that such a solution should reflect the established Charter principle that compulsion must be coupled with evidentiary immunity. I have recommended a greater role for securing US protective orders from the requesting court before enforcing letters of request. This approach is not invulnerable. However, if protective orders are respected by American litigants, they have the potential to mirror the entitlement to subsequent use immunity under section 13 of the Charter and required by the US Supreme Court decision, Kastigar. Further, by shifting the focus to the protective scope of the letter of request at the beginning of the enforceability analysis, judges would avoid considerations of the exterritorial application of the Fifth Amendment or the lack of Canadian judicial authority to guarantee subsequent use immunity once testimony travels beyond their jurisdiction. Courts could move towards a coherent legal approach that respects domestic constitutional regimes and reconciles conflicts of foreign law. 